\title{
Contemplating workplace change
}

\author{
Article
}

Accepted Version

Klag, M., Jansen, K. J. and Lee, M. D. (2015) Contemplating workplace change. Journal of Applied Behavioral Science, 51 (1). pp. 36-70. ISSN 1552-6879 doi:

https://doi.org/10.1177/0021886314564013 Available at https://centaur.reading.ac.uk/77981/

It is advisable to refer to the publisher's version if you intend to cite from the work. See Guidance on citing.

Published version at: http://dx.doi.org/10.1177/0021886314564013

To link to this article DOI: http://dx.doi.org/10.1177/0021886314564013

Publisher: Sage

All outputs in CentAUR are protected by Intellectual Property Rights law, including copyright law. Copyright and IPR is retained by the creators or other copyright holders. Terms and conditions for use of this material are defined in the End User Agreement.

\section{www.reading.ac.uk/centaur}

\section{CentAUR}

Central Archive at the University of Reading

Reading's research outputs online 


\title{
CONTEMPLATING WORKPLACE CHANGE: EVOLVING INDIVIDUAL THOUGHT PROCESSES AND EMERGENT STORY LINES
}

\author{
Abstract \\ Drawing on topical life histories of physicians in a particularly volatile public health sector \\ environment, we build theory around the contemplation of workplace change. Overall, our study \\ provides evidence as to why single or multiple independent factors like pay or job structure may \\ fail to predict or explain individual decisions to stay in or change workplaces. Instead, the \\ contemplation process is a complex, evolutionary and context-dependent one that we argue \\ requires individualized interventions. Our findings reveal the prevalence of episodic context-self \\ fit assessments prompted by triggering stimuli, two mechanisms by which thought processes \\ evolved (reinforcement and recalibration), and four characteristic story lines that explain why the \\ thought processes manifested as they did (exploring opportunities, solving problems, reconciling \\ incongruence, and escaping situations). Based on our findings, we encourage practitioners to \\ regularly engage in story-listening and dialogic conversations to better understand, and \\ potentially affect the evolving socially constructed realities of staff members.
}


In a world of boundaryless careers (Arthur \& Rousseau, 1996), fundamental shifts in the subjective meaning of work (Wrzesniewski, Dutton, \& Debebe, 2003), and the changing value of work within the greater life space (Jacobs \& Gerson, 2004), individuals are contemplating workplace transitions more frequently than ever before. Indeed, Cappelli (2000) has argued that managers must contend with the question of when rather than if people will change workplaces. However, despite these trends and the significant costs to organizations that workplace movement incurs (Hinkin \& Tracey, 2000, Waldman, et al., 2004), finding effective ways to prevent or delay turnover has been challenging. Scholars have generated an impressive list of variables that are correlated with individual-level turnover (cf. Griffeth, Hom \& Gaertner, 2000; Hom \& Griffeth, 1995). However, meta-analytic studies conclude that extant models explain no more than $20 \%$ of turnover variance (cf. Cotton \& Tuttle, 1986; Griffeth, et al., 2000). More recent studies have also begun to examine various pathways to, and motivations for, organizational exits (e.g. Lee \& Mitchell, 1994; Maertz \& Campion, 2004). These point to more complex and varied individual thought processes related to turnover that may not be conducive to representation in a single predictive model and that we do not yet fully understand (Johns, 2006). This may explain why practitioners do not seem to be reading research in the turnover domain (Holtom, Mitchell, Lee, \& Eberly, 2008; Kaye \& Jordan-Evans, 2008), contributing to an important bifurcation between scholarship and practice on this topic.

This issue became especially salient to the first author, who, as a scholar practitioner, had been following mass media stories expressing significant concern about an exodus of doctors in Quebec, Canada and about the resulting risk to the healthcare system. In fact, outmigration of physicians for Quebec had been steadily increasing for over two decades (Leduc et al., 2001). A survey study had concluded that physicians were leaving the province due to government policy related to pay levels and organizational structure (Leduc et al., 2001). Yet the first author, based on considerable experience working in the health sector, believed there was greater complexity behind these physicians' actions, particularly in light of research showing that remuneration was not among the more important workplace satisfaction criteria for physicians (Pineault, Contandriopoulos \& Fournier, 1985). Meanwhile, health 
policy researchers were also studying physician and nurse workforce issues (e.g., Kelly, 2002), not only in Quebec, but Canada-wide. In one report, researchers noted that historical recruitment and retention initiatives had shown little impact in decreasing physician exit and movement (Fooks et al., 2002). .

This setting led the first author into a lengthy intellectual journey through several bodies of healthcare and organizational literature without finding answers, and ultimately to a broader quest that is the subject of this study: to understand the full and contextualized details of how and why individuals contemplate changing workplaces. Take for example the following narrative summary capturing a young physician's thinking about a contemplated workplace transition:

\begin{abstract}
John was, in his words, on the 'speeding train' of academic medicine. After his fellowship, he had a position waiting for him at a teaching hospital, fully expecting to remain there for the rest of his career. Beginning about six months into the job, aspects of his job and of academic medicine began to concern him. He felt the normative pull to do academic research and resident training, but he actually enjoyed doing the more general aspects of his specialty. He noticed that community physicians in his specialty 'tended to be a lot happier, a lot more content' with their lives than those in academic medicine. He remembered already having developed a personal philosophy: 'medicine is my job...my life is outside the hospital with my family, my friends...' and worried when he saw his mentors giving up these important parts of their lives. 'I didn't want to be like that...that's not where I wanted to go...I feel like I had my ego pulling me in one direction and my heart pulling in another direction.' Over time, he grew increasingly angry and resentful with the mounting pressures of academic medicine. He decided that community practice would be the best road for him only eighteen months after accepting the academic position.
\end{abstract}

How is it that John begins a job, fully expecting to stay for his entire career and then over a short period of time completely shifts his thinking? Accounts such as John's, a Quebec physician and study participant, reveal multiple influencing elements that are interconnected across space and time, and a thought process providing insights into the story line that unfolded. Such richness and complexity have not been captured in the predominantly correlational studies on individual turnover, even though several studies have called for these additions (Bentein et al., 2005; Cohen, 1993; Rusbult \& Farrell, 1983; Steel, 2002; Youngblood, Mobley \& Meglino, 1983). A deeper understanding of the contemplation process could shed light on the underlying human logic (Van Maanen, 1998) of how and why these thought processes unfold. By inductively embracing the "messy" reality of thought processes related to the contemplation of workplace transitions (cf. Langley, 2009), we sought empirically based insights into ways practitioners could intervene to prevent, or at least delay, workplace transitions. 


\section{CONCEPTUALIZATION AND LITERATURE REVIEW}

We broadly conceptualize workplace transitions as movement across the membership boundaries of one or more work-related social systems (Luhmann, 1995; Price, 1977). For example, an individual may be changing work groups, organizations, industries, careers or thought worlds (e.g., public to private, for profit to non-profit or line to management; Dougherty, 1992). Social systems may be so small as to consist only of two individuals (e.g., a partnership) or may be as large as an entire society (e.g., an international assignment; Luhmann, 1995). Any workplace transition can involve changing one or more social systems. John's transition described earlier involved simultaneously leaving a unit, an organization, and the thought world of academic medicine for community practice.

We characterize the contemplation of a workplace transition as a thought process that is both embedded within, and affected by, a broader work and life context (cf. Mitchell et al., 2001).

Acknowledging that individuals may in some instances make seemingly impulsive decisions, we envision the contemplation process as one that typically occurs over time (Peterson, 1998; Langley, 1999). Although we acknowledge that there are many intra-organizational workplace transitions that may occur, including a change in work team or departmental move within the same organization (Nicholson, 1984), in this study we focused on the contemplation of voluntary workplace transitions that involved, at minimum, an inter-organizational change, as these are the most relevant in the context of this research.

To more fully understand stories like John's, we turned toward research that examines the psychology behind individual decisions to stay in or leave organizations on one hand, and research surrounding work and life transitions that have been characterized as evolutionary and multi-faceted on the other. First, the unfolding model of turnover (Donnelly \& Quinn, 2006; Lee \& Mitchell, 1994; Lee et al., 1996, 1999) offers an explanation of ways in which individuals may interpret and act upon contextual events that trigger thoughts of leaving. Other recent studies have proposed and empirically confirmed multiple types of individual decisions to leave an organization, some impulsive and some more calculated, with varying context-dependent motivational forces (Maertz \& Campion, 2004; Maertz \& Griffeth, 2004). These more recent studies begin to point to psychological processes that are more 
context-dependent, variable, and complex than has been assumed in many other generalized predictive models of individual turnover. Furthermore, a portrait of how the many inter-connected influencing elements may impact thought processes has not yet been found. Overall, many questions still remain in the literature, including an explanation of when, how and why various contextual and individual elements jointly affect and influence individual thought processes over time.

The second topic in the literature relevant and inspirational for this study is transitions, both in work and in life. Nicholson and West (1989) noted that work transition research has developed separately but in parallel with the turnover literature, when more could be learned from integrating them. More broadly, a variety of conceptual models and inductive studies on work and life transitions across several literatures informed our study (e.g. Ashford \& Taylor, 1990; Charmaz, 1995, Ebaugh, 1988; Ibarra, 1999, 2003; Nicholson, 1984). The concept of time is omni-present in this work, and there is a particular focus on interconnections of multiple elements and the evolution of individuals and their contexts. For example, both Ebaugh (1988) in her sociological study of role exit, and Ibarra (2003) in the case of career transitions, demonstrate how past feelings affect reactions to events and how events impact individuals' perceptions of their overall context and their identities. This research on work and life transitions also acknowledges that individuals undergo transitions while situated in a broader contextual environment. This assertion is consistent with Lewin's foundational work with field theory (Lewin, 1942, reprinted in 1997, p. 214), which posits that the importance of an isolated element within a situation cannot be judged "without consideration of the situation as a whole." Although there has been a dearth of research emphasizing the contemplation of workplace transition before a change has occurred (or has been planned), these contextually rich studies informed the methodological approach we adopted.

\section{METHOD}

With an emphasis on depth versus breadth for our study sample, we used a purposive sampling technique, focusing on one population in one context. We chose physicians in the public healthcare system in the province of Quebec, Canada, because at the time of the study and in the years prior there was volatility in that particular environment and reports of many physicians considering workplace 
change. There was suggestive evidence, from the popular press, physician association reports, and health commission reports, of significant frustration among physicians with government interventions in the public health system (Leduc, et al., 2001; Association Médicale du Québec, 2006; Commission d'étude sur les services de santé et les services sociaux, 2000). Physician association reports also revealed that a majority of Quebec physicians had been receiving alternative job offers (Association Médicale du Québec, 2006). These factors suggested a high likelihood of finding candidates who were experiencing thoughts about changing workplaces (Glaser \& Strauss, 1967; Miles \& Huberman, 1994). Furthermore, such volatile situations are often associated with particularly thorough individual cognitive processing and recollection (Abelson, 1963), leading to sharply-defined findings in these contexts that are also highly relevant for other more typical contexts (Bamberger \& Pratt, 2010; Pratt, Rockmann \& Kaufmann, 2006).

\section{Sample Recruitment and Characteristics}

We used the snowball sampling technique to identify potential participants. To ensure multiple sampling threads, we used numerous leads to direct us to potential participants. Following the examples of many other theory-generating studies (e.g. Hood, 1983; Ibarra, 2003; Isabella, 1990; Miles \& Huberman, 1994), we intentionally varied attributes of the sample participants along multiple dimensions that have been theorized to affect career decisions Griffeth, Hom, \& Gaertner, 2000; Kay, 1997; Lee et al., 2011; Price, 2009; Youngblood et al., 1983), including gender, workplace tenure, and family situations, as well as the nature of the change being contemplated (e.g. from one hospital to another, from a teaching to community hospital, geographic changes, career changes). We also sought diversity in terms of different physician specialties. Overall, our goal was to maximize potential diversity in narrative accounts and identify dimensions along which suggestive patterns would hold across accounts.

We employed a screening questionnaire to target participants in permanent positions (excluding trainees and residents) who had contemplated workplace change within the prior three years including those who were no longer in Quebec's public healthcare system at the time of the study. We chose a three-year time limit to obtain richer and more detailed accounts of their thought process before, during, and after contemplating a transition (cf. Ross, 1988; Ross \& Conway, 1986 Physicians were recruited at 
varying stages of development in their thought processes around changing workplaces when the interviews took place. Of the 26 physicians participating in the study, 17 had decided to change workplaces, two had decided to stay, 4 had made a commitment to stay "for the moment," and 3 were in the midst of an active contemplation process, allowing us to probe how their expectations and hopes for the future were affecting their thought processes.

\section{Study Approach}

We use an interpretive lens in this study as it is particularly suited for understanding a person's logic in explaining thought processes and behaviors (Peterson, 1998; Van Maanen, 1998). The interpretive ontology adopts a social constructionist view that individuals take action based on their interpretations of and perceptions about external phenomena (Berger \& Luckmann, 1966; Weick, 1995; Lewin, 1942 reprinted in 1997). Through this lens, we gave voice to participants' stories of their experiences in contemplating workplace transitions (Czarniawska, 2004). We focused on capturing the richness of participants' realities and the meanings they assigned to their situations, paying particular attention to the potentially dynamic, complex and interconnected contextual and individual forces that entered into their thinking (Geertz, 1973; Langley et al., 2012; Pettigrew, 1990; Tsoukas, 1989).

We utilized the life history approach to interviewing to elicit as much detail as possible (cf. Atkinson, 1998; Charmaz, 2006; Ebaugh, 1988; Goldman, 2003; Miller, 1986). This approach falls under the rubric of narrative inquiry (Chase, 2005), which "rests on the assumption of the storied nature of human experience" (McAdams, Josselson, \& Leiblich, 2001, p. xi) and involves an individual making sense of his or her personal history, with particular attention given to the temporal sequence of events, the social context in which they occurred, individual interpretations, and how events and situations lead individuals to believe and behave as they do. Informed by Ebaugh's (1988) work on role exit, we elicited topical life histories that explore histories of only one particular portion of the participant's life (in this case, that of the thought process around a contemplated workplace change).

\section{Data Collection}


Participants were interviewed face-to-face or by telephone. All interviews were recorded. The duration of interviews (excluding time for demographic questions and introduction to the study) were 69 minutes on average, with some lasting more than two hours. Additionally, we returned to seven participants to verify or clarify findings, fill in gaps noticed during data analysis, and/or learn of their progress after the first interview (Mishler, 1986; Patton, 2002). New participants were sought until information redundancy was evident. The interview began with broad open-ended questions around participants' personal and professional histories serving two purposes. The first was to allow the interviewer to develop rapport and a comfort level with participants that would then facilitate the honest and frank telling of the contemplation of workplace change stories (Charmaz, 2006). The second purpose was to provide background context to help explain their stories. The interview guides were designed to let participants tell their stories in their own language, as they would if they were telling them to friends or colleagues. The role of the interviewer was to probe, guide, and channel the discussion as necessary. When the interview context was conducive to doing so, we engaged in a laddering technique with progressive probing of "why" certain elements emerged as important or meaningful to better understand their thinking (Reynolds, Gengler \& Howard, 1995). Each interview had the potential to unfold differently, as answers to one question informed the continuing conversation, allowing us to pursue lines of inquiry that seemed promising in the interview context (Mishler, 1986).

\section{Data Analysis}

The data analysis process was informed both by Charmaz's (2006) constructivist grounded theorizing and the concept of spiraling, where the researcher continually moves both forward and backward to fine-tune the theory at multiple stages, during design, data collection, analysis and reporting (Berg, 2001). Using the individual narrative account as the unit of analysis, we analyzed their thought processes using data reduction, process modeling, reflective memos, core narrative summaries and short story lines, while acknowledging that there were also sub-plots in many of the accounts (Chase, 2005; Mischler, 1986; Miles \& Huberman, 1994). Reflective memos, which represent an early step toward theorizing and are useful in informing subsequent interviews (Glesne, 1999), were generated within 24 
hours after each interview. They summarized reflections regarding potential patterns seen relative to earlier interviews, theoretical concepts that the interviews led us to consider, questions to be asked or omitted in subsequent interviews, and/or puzzling data to which the interviewer wanted to return during the analysis. All interviews were transcribed verbatim. The transcripts were loaded into ATLAS.ti to facilitate data queries and multiple code revisions.

We engaged in two equally important and mutually informing sub-processes of dissection and reconstruction of the narratives (Glesne, 1999) as intermediate steps to theory generation. First, to keep the entire phenomenon in perspective within the reconstruction process, we reviewed entire transcripts and their reflective memos, and then attempted to reduce the data while still being able to analyze the complete narrated processes. We developed handwritten process flows to have a visual overview of "what was going on," in a preliminary attempt to establish process structures, and to understand how process components seemed to "fit" into the overall process. We did this several times, searching after each iteration for ways to usefully represent the process elements in some standardized way. These were helpful in the eventual unraveling of the range and categorization of process elements. In parallel, we created several iterations of a single model in the hopes of finding a parsimonious way to depict all the process flows. We also developed one-page summaries of each interview to capture questions such as: What was the context in which these thought processes were occurring? What were the initial expectations with respect to staying or leaving? Finally, we generated short story lines (Mishler, 1986) to answer the questions: What was the narrative really about? How can we characterize this process?

Informed by the constant comparative method (Strauss \& Corbin, 1998), we continually compared 1) data within and across accounts; and 2) data versus extant theories and concepts, both to find the best fit and to inform emerging theory. Sensitizing or tentative concepts were a central component of our analysis. Van den Hoonaard (1997, p. 16) describes sensitizing concepts as "analytical points of departure, noting that "the sensitizing concept points to something we observe but cannot yet define adequately." At any stage, even after the first interview, we allowed ourselves to take note of early theoretical concepts that we thought might be applicable. These concepts pointed us in certain directions 
during literature searches, requiring a return to the data to confirm, evolve or eliminate each of them as theory was generated (Charmaz, 2006). For example, as we grappled with the theoretical significance of a high incidence of participants' expressed views about themselves, we tentatively explored "thought worlds" (Dougherty, 1992). We ultimately discarded this concept, though the exploration of it was an important interim step toward the "activated self" that appears in the resulting theoretical model.

We dissected the transcripts via open coding, forcing us to stay intimately close to the data. We first reviewed each transcript in ATLAS.ti and created literal first-order codes (Charmaz, 2006). As we reviewed multiple transcripts and compared incidents of the same code, we refined the code labels, eliminated redundant ones, and made theoretical side-notes for later analysis. We also compared progressive coding from the interview data to handwritten visual models of the sequences of events and construed influencing elements for each story, as well as short narratives generated from reviewing the whole transcript and reflective memos. The intent was to facilitate the establishment of standardized elements across the stories as well as the ways in which these elements connected.

The continuous analysis of the dissected data (via coding) and rebuilt narratives (via multiple iterations of visual models, narrative summaries and story lines) allowed us to progressively understand and fine tune patterns in the nature and structure of the narrative accounts. The ultimate delineation of the common components of the stories as well as the links between them proved to be a useful way to elucidate the logic of their stories and the four story lines that emerged from the data (Langley, 1999; Mintzberg, Raisinghani, \& Theoret, 1976; Witte, 1972).

We report findings in two parts. We first present three deterministic and mutually influencing elements within the thought processes: triggering stimuli, focal context and the activated self. We then describe the iterative and evolutionary nature of the processes, introducing both a model that depicts how these processes unfolded and four emergent story lines that help to explain why the thought processes unfolded as they did. We include interview excerpts throughout, allowing the reader to assess the credibility and dependability of the findings (Lincoln \& Guba, 1986).

\section{THE CONTEMPLATION PROCESS:}




\section{INTERPLAYS AMONG TRIGGERING STIMULI, CONTEXT AND SELF}

In this section, we present how first thoughts about potential workplace change were triggered and how participants construed these triggers in terms of their pre-existing context, thoughts and feelings related to self, and the interface between context and self.

\section{Triggering Stimuli}

According to study participants, thoughts about changing workplaces seem to have begun with one of three forms of triggering stimuli ${ }^{1}$ : external events, taking stock of several prior events or experiences, or a welling up of negative affective states related to escalating or ongoing negative circumstances. External events were clearly distinguishable single events, while the latter two triggers seemed to represent an accumulation of aspects of the overall situation.

Fourteen participants clearly recalled single external events that triggered thoughts about changing workplaces. Six of the fourteen events occurred in participants' workplaces, were perceived to be negative, and seemed to be shocking or jarring. These events resembled the shocks that trigger the unfolding model of turnover (Lee et al., 1996, 1999). For example, Participant 8 described a single event with a cancer patient for whom she was unable to secure operating room time. For her, this was the event that, quite suddenly, triggered thoughts about changing workplaces:

What happened to him was just unspeakable. So, and that to me, that was the straw that broke the camel's...that was the first time when I said I can't stand it anymore. And that was the first time I spoke to my husband about leaving. We had never talked about it before.

Six other clearly discernible external triggering events for participants were potential alternative job opportunities that were viewed positively by participants. For example, participant 23 noted, "The Dean from University X tried to recruit me.” For two other participants, the triggering event was simply the arrival of a particular time point. For example, Participant 19 had previously decided that he and his

\footnotetext{
${ }^{1}$ Note that participants were not asked if there was a specific event. They were simply asked to talk about when they first started thinking about a transition. This allowed us to see what kinds of triggers emerged from them, in their own language.
} 
wife would reassess their job situation after one year. As the one year anniversary passed, it triggered thoughts about changing workplaces.

A second form of triggering stimuli was taking stock of prior events and experiences. Seven participants experienced initial thoughts of leaving as they took stock of either a wave of events that had unfolded over a period of time, or an experience that had taken place over time. For example, Participant 4 discussed multiple events that, together, triggered his decision process:

The amount of work went down because all the [specialty] surgeons left, and they were unable to recruit any more ... and then in the process of building that emergency room, they blocked off all the windows in the operating room, so suddenly in that operating room, which hasn't been renovated since the 1950's, it has a black floor and green walls and is just the most miserable old place full of unhappy people and... when they blocked off the windows, that was the final stroke... it was more a combination of...I'd been there six years, the traffic, the closing of the wi-... guess the final straw was the closing up of the windows, all the [specialty] surgeons - it was very multi-factorial.

Participant 18 had acknowledged an issue she knew she would have to address at some point; she felt she had to be close to her boyfriend. She eventually took stock of the situation and felt a need to take action after having spent a year apart from him.

The third form of triggering stimuli, experienced by five participants, was the welling up of negative affective states. This form was characterized by pre-existing negative emotions or feelings of fatigue or strain, related to a previously acknowledged nagging issue that led them to contemplate a transition. The affective states seemed to be constituted by both vague emotional states with no specific perceived precipitating event (Weiss \& Cropanzano, 1996) and a general sense of lack of well-being reflected in participant comments that "things were not going well," characterized by reported fatigue, strain or even perceived burnout (Maslach, Schaufeli \& Leiter, 2001). For example, Participant 14's escalating frustrations bubbled up to the surface, precipitating first thoughts of leaving:

.... and so after two years, we got nowhere with getting any movement and so we said, "Look, let's forget it. This is ridiculous. I can't do this. So, I can't continue to work one in two call and on top of it have no administrative infrastructure support to do any of the other things that I really, that I got trained to do. I didn't get trained just to do the clinical call. I got trained to help run a trauma program in a major city. And if I'm not doing ..." At that time, we both got kind of very, just felt there was no way that we were going to accomplish what we wanted to accomplish in our careers here.

Participant 24 described his first thoughts about potentially changing workplaces as a tipping point amidst escalating frustrations with his situation: 
...so I was feeling more and more stressed to perform at a certain level, being pushed from below but not really helped and not being pulled from above and, you know... at some point I said, you know, that's enough, I'm tired...

\section{Consideration of Context}

Overall, the triggering stimuli seemed to precipitate an assessment of participants' overall situations and particular aspects of their pre-existing contexts. The data revealed four aspects of participants' construed contexts that seemed to be considered as a whole, including aspects of perceived work and non-work circumstances, construed characteristics of the social systems in which they worked or imagined working, and recollections of particular prior events and experiences.

The first three dimensions were consistent with Cappelli and Sherer's (1991) conceptualization: work circumstances or other things going on at work that participants deemed relevant, such as having to work very long hours; non-work circumstances, such as being geographically bound because of strong family ties; and characteristics of the individual's social systems including teams, departments, hospitals, and the provincial healthcare system, as a comment from Participant 22 illustrates:

There are too many problems with the system...problems with staff...it's a bit like that across Quebec due to policies that have been put in place over the years.

Lewin (1942) referred to the constellation of salient contextual elements as the contextual field or the broader situation at the time of the onset of a particular stimulus.

The fourth dimension resembled what Shipp and Jansen (2011) refer to as temporal context, composed of the recollection of prior events or experiences as well as anticipations of future experiences (see also Murray, 1938). For example, Participant 2 experienced discrete events such as the shortening of on-call hours, as well as changes in the patterns of practice over time that influenced her thoughts about making a change. This latter example carries meaning beyond discrete events, highlighting the recognition of patterns and evolving processes as part of the temporal context.

The data further revealed that there was a variety of focal social systems considered, often more than one for a particular participant, suggesting that the construed context was multifaceted. Importantly, the social systems driving participants toward changing workplaces most often did not include the 
organization. For multiple participants, construed context related to one or more social systems nested within the organization, including a team, a department, or a group of specialists. In other cases construed context related to social systems in which a single organization was nested, including the professions of academic medicine and community medicine, the provincial healthcare system or even a city or country. For example, Participant 17 was thinking about leaving the provincial healthcare system, although he claimed to be very happy with the hospital within which he worked. He also had many meaningful ties to family in his city that played a role in his ultimate commitment to stay in his workplace. In this case, two social systems (i.e. his hospital and his family in that city) had a buffering effect with respect to frustrations within a third social system (the provincial healthcare system). Therefore, even for individuals who were physically thinking about leaving a hospital, they were often psychologically considering leaving other social systems, in addition to, or instead of, their organizations.

\section{Consideration of Self}

Participants' assessment of the situation also included consideration of themselves. The data revealed four dimensions of the self that seemed to enter into these assessments: their views of self, their needs, their values, and their affective states. First, 23 out of the 26 participants compared and contrasted their contexts to their views of who they believed themselves to be, images of who they did or did not want to be, or images of who they saw themselves becoming in the future, to explain their decision processes. This dimension resembles Markus and Wurf's (1987: 301) view of working self-concept as a set of past, present and/or idealized future "images, schemas, conceptions, prototypes, theories, goals, or tasks."2 Participant 3 illustrates how her current workplace was not allowing her to be who she felt she was with respect to her approach to medicine and the kind of work she imagined herself doing:

I am not comfortable doing surgery like the older [her specialty] surgeons do...

I am very pointilleuse [meticulous] ...I pay a lot of attention to details in [her specialty] surgery... I am doing...secretary work... I should not be doing that...

\footnotetext{
${ }^{2}$ We distinguish between self-concept ("who I am") and social identity ("the image I convey to others"), recognizing that social identity may contribute to the development of self-concept. We adopt the term working selfconcept to acknowledge that only a subset of self-conceptions are malleable, accessible and invoked at any one point in time (Markus \& Wurf, 1987).
} 
Second, our data revealed many kinds of unfulfilled needs related to participants' external job and life context and, in some cases, to overall feelings of well-being. For example, Participant 5 clearly expressed his need to do research, which he was not able to do to his desired extent. One of his concerns with his workplace was the lack of time to do research. Another example is Participant 7, who had an unfulfilled need to increase his remuneration.

Third, the data also suggests that personally important values were at play. An example of a value was the importance Participant 7 placed on ensuring that his family was happy, "Number one for me is obviously that the kids and my wife are happy." Another example in the study data was the importance, for Participant 8, of providing quality care to her patients, as shown in the excerpt below,

It was not professional. It is not the way I would have liked to be treated. I was not able to treat patients the way I would have liked to be treated and the way I would have liked my family to be treated. That might be a very simplistic way to look at it, but, uh...but that's the way I look at it.

Fourth, making sense of triggering stimuli seemed to activate prior underlying affective states such as frustration or anger, general feelings that "things were going well," or feelings of fatigue or strain. For example, Participant 6 remarked on the strain under which he was working as thoughts about leaving were re-awakened after a dormant period of trying to "make a go of things" in his position:

\footnotetext{
"And the rude shock, the awakening came when I realized when I arrived in what had been assigned to me as my office, only to find out that the same office had been promised to two other people...it was the office and it was also getting the lab assigned to me and finding out in a casual conversation with somebody who had been in the space before that they had left the space because there were toxic fumes coming out of the hood...I mean there was anger and betrayal. I mean there was tremendous anger. And that doesn 't' help. And I mean there were other issues too..."
}

Visible affective states, even during the interviews, varied considerably across participants. At one end of the spectrum, Participant 17 provided passionate, lengthy, and emotion-laden responses, likening the interview to a therapy session. At the other end of the spectrum, Participant 15 focused solely on answering the questions, with no mention of any psychological or emotional impact. This pattern of variation may be related to affect intensity (Larsen \& Diener, 1987; Larsen, Diener \& Emmons, 1986), an individual difference characteristic reflecting the strength of emotional reactivity and variability, or the life impact the contemplation process represented for the participant.

The various dimensions of "self" seemed to operate as a multi-dimensional gestalt (i.e., personal subjective life space; Lewin, 1942). Participant 8, for example, clearly experienced value violations; she 
believed that patients deserved a certain quality of care that she was unable to maintain. At the same time, she noted an underlying unhappiness. Together, these conditions, which were likely linked, contributed to her subsequent decision to take another job.

\section{Context-Self Comparisons}

Participants frequently made comparisons between various aspects of their contexts and their views about themselves as they described the triggering stimuli and the resulting situational assessments. At the core of these context-self interconnections seemed to be a drive for congruence, as shown in the excerpt below demonstrating how John, whose narrative we summarized earlier, sensed incongruence between his views of his work and life context (in this case, his institution and academic medicine more generally) and his views of himself. He explained these developments in response to an interview question about when he first started thinking about changing workplaces:

There's rounds, there's teaching sessions, and this and that. Some of it is fun, some of it is stimulating, but it just... adds on to my day. So Wednesday when we have rounds, I'm home at 7:00. And yes they're stimulating, but, you know, like I want to reiterate, um, medicine, and I keep telling myself because I don't want to fall into the trap. Medicine is my job and my life is my kids now ... and family.

Later on in his story he added:

... when I was a chief resident...I was on the... resident selection committee for residents coming in that next year. And really, you know... who was important? Those who had big stuffing CV's, and how many projects they worked on, and papers they worked on, and uh, those, you know, one of the big questions "where do you want to be10 years from now?" And if someone said, "Well, I want to be out in [X city] practicing [X specialty]," we didn't even give it a second thought. We sort of chuckled behind our things and the guy was out the door. If you...said, "Well, I want to be a professor of, you know, epidemiology and statistics in the department of $[X]$," whatever, "that's all, you're in. Sign on the line!" So, you're really brainwashed into thinking that this is the only way and everything else is, is sub-standard. And that's, that's something that's stuck in our mind that's hard to shake. Um, but I started to, again, really be out [in the community] and started to see that there's a whole other world out there.

In the excerpt below, John also communicated perceived incongruence between his views of certain aspects of his context and what he liked, who he was, and who he wanted to be.

I enjoy seeing patients. I think that's what I'm good at. I'm good with people. You know, I think patients like me, I think they feel comfortable with me, uh, and, you know, on the whole, that's, that's what I enjoy. Uh, I'm not a basic scientist, I'm never going to be a basic scientist... but you know we were getting involved in... it wasn't basic science, it was more in the field of laparoscopy and I saw, you know they push you early on, to try to get tenure, and then I see some of my people four or five years ahead of me who didn't get tenure and I saw them kind of, you know, papers and they were really gung ho and I'm like, I'm never going to get tenure with my little... animal projects... and doing surgery on pigs...you know? It's a little...claustrophobic to... be in a place where you may not, you see that you may not, not belong... 
Whereas some of the context-self comparisons seemed to be quite rational, others seemed more emotional, with negative emotions such as anger and frustration unleashed alongside comparisons between one's self and one's context. For example, Participant 5 described what seemed to be a rational assessment of the inconsistencies between his view of his context and of himself:

It was probably after I did my six weeks...at the [xx ward]. I had the opportunity to see ...to interact with other colleagues and ... to see how the work goes... and I say, no, this is not the environment I want to be...the quality of care...the knowledge basis that I found in my colleagues.

In contrast, Participant 4, who, according to his story, seemed to decide to change workplaces quite impulsively, recounted a more emotional response to an untenable clash between himself and his context. The following excerpt illustrates his felt tension when the hospital changed the work environment: ...when they blocked off the windows, that was the final stroke...you know, I didn't leave [X country] to come to Canada ...to work in some black stinking hole."

This participant was seeing himself as an individual who left another country for "greener grass." He viewed his institution as a "black stinking hole," inconsistent with his view of where he should be.

Participant 6 noted when the triggering stimulus in his process occurred (the non-availability of physical resources he had been promised), "I mean there was anger and betrayal. I mean there was tremendous anger." In addition to the need that had not been met, he felt this was unjust. Participant 17 reacted with anger to the proposed government legislation that prompted thoughts about leaving:

That, uh, an ex-physician health minister could really propose such terrible legislation. That was very difficult. So it was really a two-pronged thing. Let down by our leadership and you could hear the doctors grumbling, "Who's in charge? Let's go out on strike. Let's shut down the goddamn hospital for two days and talk turkey." And I would have been prepared to do that. I said I was willing to go to jail. That's how angry I was...

Participant 8 , who was quoted earlier regarding a triggering stimulus of being unable to confirm a surgery date for one of her cancer patients, had a strong emotional reaction:

What happened to him was just unspeakable... That was the first time when I said I can't stand it anymore. ...The gentleman was 55, he had a cancer of the [X], I saw him in the first week of June and I was scheduled to go on vacation on July $15^{\text {th }} \ldots$ and I did not have a single minute of operating time in those six weeks to operate on him... So this guy had a cancer and I couldn't bump somebody else who had a cancer to do him...So...I said I am going to put you on the wait list. Well, it happened to be a patient who was particularly nervous. He called the office every day, crying on the phone. Begging to have his surgery: "PLEASE do something, my life is in your hands. I will pay you" ... and there was nothing I could do about it. Because there was no O.R. time! I was totally, totally unable to help him in any kind of fashion ... what was absolutely inhuman for this man is that if I had seen him in the office and told him 'your surgery is in 
two weeks', it would have been a lot of agony, but he would have known. He did not know from day to day when he would have his surgery. He had no clue. This is not a way to treat people

\section{THE UNFOLDING CONTEMPLATION PROCESS: ITERATIVE EPISODES AND EMERGENT STORY LINES}

In examining triggering stimuli, context, self, and context-self comparisons, we have described participants' episodic recollections of thoughts and feelings about a contemplated workplace transition. However, the data from this study also showed that participants' assessments of their situations seemed to be fluid over time, in that there was often a series of episodes, provisional actions and tentative decisions along the way. The data also revealed four representative story lines capturing the varied nature of the evolution in this process over time. We describe these findings in more detail below.

\section{Iterative Episodes}

Multiple stimuli seemed to precipitate iterative episodes of construing and, in some cases, acting upon these stimuli, for 24 of the 26 participants (the remaining two participants seemed to make spontaneous decisions to leave). This stands in contrast to the unfolding model of turnover proposing that a single shock or jarring event initiates thoughts about leaving, leading directly to a cognitive decision process and turnover (Lee \& Mitchell,1994). As an extreme example of iterative events, Participant 26 actively contemplated making a change every month after her seven-day on-call service:

Every time I finish a long period of being on service, and I'm exhausted and I having nothing in, in terms of academic performance, I think I might as well be in private practice in [another city outside Quebec] .... and is it worth it?...there's really not a month that goes by that I don't think about leaving Quebec...seriously.

The iterative episodes sometimes led participants to make some form of interim decision, such as committing to explore alternative job opportunities. However, they were often tentative decisions to "stay for the moment" and subject to change later on. For example, Participant 10 made a decision, after turning down an opportunity, to stay put for at least another seven years, until his children were older. He was clearly still thinking about transitioning one day in the future. Certain participants reached "predecisions" or commitments to change workplaces at a future point when they would secure another job.

Each iteration precipitated an evolution in how participants viewed their overall situations, taking one of two forms: a reinforcement (positive or negative) or recalibration of prior situational views. In 
some cases, events reaffirmed participants' commitment to stay. In other cases, events added fuel to the fire, reinforcing the prior situational view and making a negatively construed situation seem even worse. For example, Participant 24 talked about how he had begun contemplating changing workplaces, and how he had been experiencing significant fatigue and frustration over time. When he learned that a new department head had decided not to join, it reinforced his commitment to leave.

Alternatively, some events led to a recalibration or shift in prior situational views. For example, based on a series of events, Participant 3 thought she was in line for a new position. However, after a difficult meeting with her new department chair to discuss the position, she became aware that the position would not become available. This incident led to a recalibration of her prior situational views. Though she did not immediately decide to leave the province of Quebec at that point, she began to think more seriously about it. Recalibration sometimes occurred within the self. For example, Participant 26 noted that she had felt her sense of self change over the course of her thinking, particularly when, at a certain point, she felt she would stay in her workplace for the time being. By the time she was interviewed for the study, she stated that her sense of self was less "tied up" with her career. This recalibration was not, in and of itself, provoking action at the time of the interview. However, it had played a role in her interim decision to stay "for the moment."

Recalibration points were particularly visible for 13 of 17 participants who ultimately decided to change workplaces, and who reached a clear point of realization where the scale had been clearly and permanently tipped in favor of changing workplaces. For example, Participant 19 noted as he discussed this moment of clear realization "...It was time for me to look someplace else...I clearly was not going to stay in...[X city]." In other cases, this recalibration was more subtle, taking the form of a shift in thinking that changed the character of the overall situation in which subsequent stimuli were construed. For example, five participants, including John, recounted that when they joined their institutions, they fully expected to stay in their workplaces for the long term; yet they ultimately left. In attempting to understand how these individuals made sense of this shift from such strong expectations to stay to 
decisions to leave, we reviewed their transcripts and found that four out of five of these participants described a posture shift over time from being "closed" to the idea of leaving to becoming "open" to it.

This transition from closed to open came with specific stimuli construed under conditions of long-standing frustrations or sub-conscious doubts that were brought to the surface during these moments. For instance, Participant 20 became open to other opportunities after unsuccessfully attempting (with no support from his institution in his view) to engage in new scientific research projects in his institution. At a certain point, after multiple negatively construed events and associated growing frustrations, there seemed to be a recalibration of how he perceived his overall situation. He came to believe that he would not be able to engage in the work he wanted if he stayed, and became open to other options:

...during that reflection...you know when you start questioning things...you start opening your mind to...other things...job offers come a lot... and I think it had been since '97 I had not considered another job...

A Model of the Iterative and Evolving Interplays. Based upon the findings reported above, we developed a model of the iterative process that unfolds as participants contemplate a workplace transition. As depicted in Figure 1, a triggering stimulus initiates an assessment of the construed situation (Arrow A). The construed situation is the dotted-line box (indicating fluidity with the external environment) within which activated aspects of the self and the focal context became the basis for assessments of congruence and emotional reactions. The congruence assessments sometimes led to a reinforcement or recalibration of the overall situation, which in some cases prompted provisional actions and decisions (Arrow B). The evolved situational assessment then becomes the new interpretive ground for subsequent triggering stimuli (Arrow C). This iterative model highlights the evolutionary and interconnected nature of the multiple influences at play as individuals contemplate a transition. It also begins to explain why intervening to change one or two factors at one point in time without attention to context, or to the salience of these factors for the focal individual, may simply not yield the desired result.

$$
\text { *** Insert Figure } 1 \text { about here } * * *
$$

\section{Emergent Story Lines}


Notwithstanding the overall process model in Figure 1 that held across participants, we also found ourselves struck by the significant variation in the underlying themes, richness and tones of the individual stories we heard from participants. This variation prompted our search for identifiable patterns in the dominant "plot" or story line for each account. ${ }^{3}$ An iterative process of examining similarities and differences across process story lines using constant comparison (Strauss \& Corbin, 1998) revealed four story line types that provide a more textured understanding of not only how but why the various contemplation processes progressed as they did (Hood, 1983).

\section{Story Line 1: Exploring Opportunities.}

"I've never actively thought about leaving except when people came to me." (illustrative quote from Participant 23)

The five participants classified in this category had not been actively looking to leave, nor did they claim to be unhappy in their workplaces when their contemplation process began. Their overall work contexts were construed to be positive or neutral. The driving force in these processes seemed to be unsolicited alternative opportunities that presented. These triggered (and in most cases iteratively reactivated) thought processes surrounding their potential pursuit. The processes unfolded in this way iteratively as each new opportunity presented. For four of the five participants, the exploration of opportunities was accompanied by learning about, and reflecting on, the extent to which these opportunities would meet their needs or were consistent with their goals and aspirations. These participants were open to leaving for the "right" opportunity. One participant seemed to jump to a decision with no interim exploration or deliberation in order to take advantage of an opportunity. However, upon further investigation, he had, over the years, thought about and discussed the idea of this alternative. Thus, once the opportunity presented, he jumped at it without much immediate thought.

\section{Story Line 2: Solving Problems.}

\footnotetext{
${ }^{3}$ Note that the variations identified did not occur on the dimensions along which we intentionally varied the sample: social system movement, gender, workplace tenure, family situations, specialties and mother tongue. The inductively derived story line types seemed to hold across these intentionally varied dimensions.
} 
"I'm in a job that I like, I like the people I'm with...it's not like I'm in a bad situation, it's just that there are a few things that are not ideal and I'm thinking about ways of improving them." (illustrative quote from Participant 7)

For three participants, a particular work or non-work related need that was not being met represented both a problem to be solved and a driving force in their contemplation process. These three participants showed evidence that they generally construed their overall work contexts to be positive, but felt a need to consider changing jobs as one of multiple options to resolve their particular problem. For example, Participant 18 wanted to find a way to be with her partner who was working in the U.S. She had hoped he could come to Quebec, but this was found to not be feasible for him. Ultimately, she left to be with him, though professionally she would have preferred to stay in her Quebec workplace. Rather than being driven by a sense of job dissatisfaction, the processes in this story line seemed to be triggered by the acknowledgment of an identifiable problem within an otherwise satisfying workplace.

\section{Story Line 3: Reconciling Incongruence.}

"I had a plan to stay there I think, but I'm not the kind of person that would stay in a place if I did not get what I wanted from my career. So, I had an idea, I have still an idea of what my career should be and I will move until I find that." (illustrative quote from Participant 3)

For the eight participants classified in this story line, their processes were characterized by the emergent realization that professional and/or personal needs consistent with their career and/or life visions were not being met and would not be met in their current workplaces. During their contemplation processes, these participants focused not only on past and present problems but also on their prospective future. Contrary to the problem solving story line, these participants felt a nagging, and, for some, escalating sense of incongruence between their overall work situations, which they construed negatively, and their views of who they defined themselves to be, their overall career needs and/or their life needs. This incongruence was accompanied by significant frustration, anger, feelings of strain, and/or fatigue.

When participants in this story line first joined their current workplaces, five out of eight of them had fully expected to remain for the rest of their careers. However, they described escalating frustrations and attempts to make things work, with seven out of the eight eventually reached a moment of realization of ultimate futility. According to Ibarra (2003), these moments "make it clear that there is no turning 
back...they signal that we are ripe for action, make us more attentive to new ideas, and trumpet our readiness to those around us."(p. 141). During these moments, the scale tipped in favor of leaving; there seemed to be a psychological decoupling of participants from their workplaces. The contemplation processes seemed to follow a pattern of doubts emerging, a moment of realization, and then an increase in momentum as participants began to actively engage in the pursuit of alternative opportunities.

\section{Story Line 4: Escaping Situations.}

"That was just too much, it drove me over the edge..." (illustrative excerpt from Participant 8)

There were nine participants classified in the fourth story line. Their stories were about the felt necessity to escape what they viewed as untenable working conditions or circumstances under which they were working. Frustrations accompanied these views related to lack of resources and the resulting inability to provide quality patient care, unpleasant working conditions, or operational inefficiencies. Similar to the third story line, these participants reported negative evaluations of the work situation and mounting frustration. However, rather than unmet life or career needs in relation to work, they emphasized intolerable work conditions that they could no longer bear.

This story line differed from story line 3 in that the contemplation process typically involved threshold breaking or destabilizing events. These events triggered a clear direction, with significant momentum, toward leaving. The processes followed intermittent "ups and downs" or work context interference until a significant, and in some cases, explosive event occurred that brought forth strong negative emotions and shifted the process to one with a steep slope toward leaving, following a pattern similar to punctuated equilibrium (Sheridan \& Abelson, 1983; Gersick, 1985).

These threshold-breaking or destabilizing events involved violations of ethical values or a sense of right and wrong for all nine cases in this category. The value violations were related to either perceived obstructions in providing quality patient care, and/or perceived unfair treatment with respect to compensation and working conditions. For example, Participant 1 spoke about his frustrations with having to provide care within a healthcare system that he felt was not committed to proper patient care: 
The system has decided that sick people are expensive. It's not willing to spend money properly to prevent people from getting sick. It's not willing to change life habits or discourage certain things that make you sick. It's not willing to provide effective screening for certain things so that you can find diseases sooner. All the ripples that occur from having that disease are not as serious if you find it sooner. It tells people that they have access to care but then doesn't fund that access to care...So you are allowing the doctors to foster the illusion that the quality of the care that is being provided is adequate...I used to say, "I don't have a problem with that but you have to put up a sign in front of the hospital saying: 'We don't provide full care. And our doctors are just following orders. '...No sign ever appeared. Just signs saying 'Please donate.'”

Seven out of nine participants in this category discussed anger, frustration, and/or unhappiness that accompanied their perceptions of their work contexts, and eight out of nine participants also reported experiencing strain, fatigue and/or burnout. These psychological and emotional states came to a head with the onset of the destabilizing or threshold-breaking events. Participant 11 was convinced that she would have been diagnosed with burnout had she sought professional help. Months after leaving and joining another institution, she felt she was still suffering these effects. At the time of the interviews, six of the nine participants in this category had changed workplaces and four of those made their decisions even before securing other jobs. Two had decided to stay in their workplaces in spite of a threshold-breaking event (proposed legislation by the government), because it was subsequently rescinded. One participant had not yet decided whether she would stay or leave. According to her, her characterization of herself had evolved, placing more priority on family and non-work life in general.

Characteristics of the Four Story Lines. Figure 2 summarizes the four story lines and the number of participants classified in each. ${ }^{4}$ As is evident from the descriptions above, each of these story lines was characterized by a distinct constellation of characteristics. As shown in the figure, the story lines varied along four dimensions: work context evaluation, focal point of contemplation, scope of change, and emotionality. The line between story lines 2 and 3 in the figure represents a faultline of sorts (Lau \& Murnighan, 1998), dividing the four story lines into two clusters and emphasizing a wider disparity between the two clusters than within each cluster.

\footnotetext{
*** Insert Figure 2 about here $* * *$
}

\footnotetext{
${ }^{4}$ One participant was not assigned to a dominant story line because he seemed to cycle between story lines 3 and 4 over a period of five years. We explore this unique progression and potential implications in the discussion section.
} 
First, we noted differences in participants' general evaluation of their current work environment. Participants in the first two story lines were generally satisfied with their work environments when the opportunity or problem presented. In these cases, their perceptions of their overall work contexts either did not play into the thought process, or acted as a counter force against leaving. In contrast, participants in story lines 3 and 4 construed their work environment negatively, which played into their contemplation process. This combination, according to participant accounts, contributed to a push toward leaving.

Second, the story lines also diverged in terms of the focal point of the contemplation. In the first two story lines, participants primarily engaged in extrospection about their situations, focusing their contemplation on actual and perceived changes in their work or non-work context that precipitated thoughts about changing workplaces (Shipp \& Jansen, 2011). In contrast, there was far more introspection present in story lines 3 and 4, where real questioning and consideration of core values, needs and self-concept were more instrumental in the contemplation process.

The third dimension captures the scope of change and the manner by which the contemplation process unfolded over time (Nadler \& Tushman, 1989). The first two story lines followed a path of incremental change, following more of a step-by-step thought process that unfolded as events occurred. The second two story lines evolved in a more punctuated manner, with evidence of moments of realization or threshold-breaking events signaling that their context had fundamentally changed.

Fourth, the narrative accounts varied in terms of emotionality. The first two story lines were characterized by relatively rational assessments of self-context congruence. Story lines 3 and 4 seemed more emotion-laden, showing evidence of more intense and engaged thought processes. The majority of participants in story lines 3 and 4 talked of experiencing a crescendo of negative emotions, strain and fatigue during, and leading up to, their contemplation process. They also recounted their experiences with more passion and detail. In fact, narrative accounts for these individuals were longer and made more references to negative affective states, on average, than those in the first and second story lines.

\section{DISCUSSION}


Our goal was to understand how and why individuals contemplate changing workplaces, shedding light upon how someone like John, with full expectations of remaining in his current position for his entire career, considers and then ultimately leaves both his workplace and academic medicine in less than two years. The answer lies in an iterative and evolving interpretive process, with re-assessments of his situation over time, and his emotion-laden "reconciling incongruence" story line that ended in a transition to a community-based position more congruent with his evolved self-concept. This study reveals a process with a specified repertoire of influencing elements that raises awareness of potential interventions that might prevent or mitigate physician transitions from one social system to another. It also addresses scholarly calls for further consideration of process (Holtom et al. 2008), by understanding how the contemplation process actually progresses in a person's mind, and practice (Steel \& Lounsbury, 2009), by focusing on physician transitions in Quebec during a particularly tumultuous time.

Over and above the empirically-derived framework for understanding individualized thought processes, this study provides several other insights into the human logic behind the contemplation of workplace transitions. First, we identified mechanisms of recalibration and reinforcement in the evolution of situational assessments over time. Reinforcement reaffirms the prior situational view, bearing some resemblance to escalation of commitment (e.g., Staw, 1981). Alternatively, recalibration reflects a shift in how the situation had previously been construed. Second, these mechanisms were sometimes accompanied by critical points in the evolution of the contemplation process, such as shifting from being closed to open to the idea of changing workplaces and experiencing moments of realization leading to punctuated change in the direction or intensity of subsequent thoughts. Third, we saw evidence of provisional decisions such as stay for now, which call into question the long-held dichotomous outcomes of staying or leaving. Finally, the four story lines (exploring opportunities, solving problems, reconciling incongruence, and escaping situations) by which the process unfolded over time provide a rich and holistic window into the varied logics of progression through the contemplation process.

\section{Theoretical Implications and Future Research}


The findings from this study contribute important theoretical insights to research on personenvironment (PE) fit, turnover, and work transitions, particularly in terms of the interface between context and self, the role of emotions, the importance of time, and the storied nature of the process.

The context-self interface. Our findings are consistent with, and build upon, the central concept of context-self congruence across a variety of domains (e.g., Aquino et al., 1997; Kristof-Brown \& Jansen, 2007; Lee \&Mitchel, 1994; Lewin, 1942; Perls, 1973; Schneider, 1985). Findings specify the salient elements related to context and self as well as the nature of the interplay between them.

Interestingly, self-concept played a significant role in participant thought processes, particularly for story lines 3 and 4. Self-concept has long been an important concept in the study of career choice (e.g. Super et. al, 1963; Schein, 1996), life transitions (e.g., Kling, Ryff, \& Essex, 1997), commitment (Johnson \& Chang, 2006), and identification and personal growth (e.g. Pratt, 2000). That said, it has been relatively understudied in the PE fit and turnover literature (for exceptions, see Roberts \& Robins, 2004; Rode, Judge, \& Sun, 2012). Further research can explore the role that self-concept plays in the fit narratives that are crafted (Shipp \& Jansen, 2011), and how incongruence between self-concept and work context contributes to turnover decisions (Cowin et al., 2008; Gibson, 2003).

Our findings also provide a more nuanced understanding of both the nature and the important role of context in these congruence assessments. For example, much of the PE fit literature assumes that the "environment" is the organization (e.g., Kristof, 1996) or the job (e.g., Edwards, 1991). Instead, this study supports job embeddedness research (Holtom \& Inderrieden, 2006) by demonstrating that a multitude of focal social systems and contextual factors may be relevant in thoughts about staying or leaving. It also further builds on this research stream by demonstrating how multiple social systems may jointly play into the thought processes that underlie stay-leave decisions and even how perceptions about one social system (for example, one's department in a hospital) can mitigate or have a buffering effect on, negative perceptions about another one (for example, the healthcare system in Quebec). Importantly, even though individuals may ultimately physically leave an organization, the focal social systems relevant in their assessments of congruence may, in some cases, not be the organization per se. Future research that 
considers contextual embeddedness (e.g. Mitchell et al., 2001) and interdependencies among levels of focal social systems may add further depth to the under-researched mechanisms at play in staying in one's workplace despite being unhappy and feeling a pull toward leaving.

The central role of emotions. Findings from the present study underscore the prevalence and importance of emotions, consistent with the work and life transition literature reviewed earlier. However, emotions have been relatively less studied in the turnover and fit literatures. In fact, prior to the introduction of the unfolding model (Lee \& Mitchell, 1994), turnover research had generally been characterized as a rational and cognitive process devoid of emotions and psychological states (Harman et al., 2007). There is an emerging interest in understanding the links between emotions and turnover intent or behavior (e.g., Harlos, 2010; George \& Jones, 1996; Holtom, Burton \& Crossley, 2012; Pelled \& Xin, 1999). Our study specifies how affect may influence the interpretive processes: the welling up of negative affective states as a triggering stimuli, the affective state of the self, and the emotions that emerge from the situational assessment, particularly for story lines 3 and 4.

Within the fit literature, the presence of emotions that appeared as individuals compared the activated self and the focal context can be interpreted in one of two disparate ways, depending on one's epistemological perspective. First, some would argue that what we identified as emotion-laden congruence assessments is not congruence at all. Instead, an individual's perception of congruence can be seen as a contamination of the fit construct, which can be avoided with independent measures of the person and the environment (e.g., Edwards et al., 2006). Alternatively, others would argue that perceptions of congruence are more predictive of actual behavior (Cable \& DeRue, 2002), and emotions are a natural by-product of misfit (Billsberry et al., 2005). We tend to ascribe to this second perspective. We believe that our exploration of these interpretive processes highlights that emotion and cognition are inextricably interconnected (Solomon, 1993), and that emotion indeed plays a role in assessments of congruence, adding to a limited set of research examining affect and fit (Gabriel et al., 2014; Harris \& Mossholder, 1996; Yu, 2009). These preliminary findings may indicate a need for further research to understand the extent to which affect, and perhaps the quest for positive affect, drive turnover decisions. 
The importance of time. This study informs a variety of process-oriented work transition literature, from entry (e.g., Kammeyer-Mueller \& Wanberg, 2003; Louis, 1980), to interim adjustment (e.g., Dawis \& Lofquist, 1984), to exit (Bartunek, Huang, \& Walsh, 2008; Ebaugh, 1988; KammeyerMueller et al., 2005). Findings also add to an emerging body of theory and research examining the thought processes that unfold from perceived fit, or lack thereof, to eventual turnover (Donnelly \& Quinn, 2006; Holtom, Mitchell, Lee, \& Inderrieden, 2005; Holtom \& Inderrieden, 2006; Jansen \& KristofBrown, 2006; Lee and Mitchell, 1994; Lee et al., 1996, 1999; Shipp \& Jansen, 2011).

Although the fit literature long ago recognized the importance of history and temporal context (Murray, 1938; Caplan, 1983), as has some of the more recent turnover literature (e.g. Steel, 2002), empirically-derived frameworks that account for these have been less evident. The fit literature has only recently developed theory on the role time plays in assessments of fit (Jansen \& Kristof-Brown, 2006; Shipp \& Jansen, 2011). Shipp and Jansen (2011) developed a conceptual model proposing that, through processes of extrospection and introspection, individuals craft a temporally-situated narrative to make sense of their current fit with their environments. Our participant narratives support this model, showing that congruence perceptions were fluid with the passage of time as individuals assessed and re-assessed their situations with the onset of important events. This study further contributes to the literature by specifying how time affects the contemplation processes and outcomes as individuals construe stimuli in light both of past developments and future anticipated ones.

Storied nature of the contemplation process. The four identified story lines characterize contemplation processes that varied in terms of overall evaluation of the work environment, introspective versus extrospective focus, emotionality, and evolutionary versus revolutionary scope of change over the course of the process. Capturing the archetypal stories of these processes helps both scholars and practitioners combine many interdependent factors and considerations into a coherent whole that can be easily understood and articulated (Chase, 2005; McAdams et al., 2001). To further develop the nomological network related to these unfolding processes, future research can compare these story lines with related concepts, such as Maertz \& Campion's (2004) quitting profiles, which focus on final 
deliberations to leave. A cursory juxtaposition suggests similarities with two of the four quitting profiles (comparison and conditional). Further exploration along these lines may generate other categories of the conditional quitting profile, or additional contemplation story lines.

As mentioned earlier, one of our study participants, who stayed in his work environment despite intense and longstanding frustration, was not easily classified into one story line. Instead, he seemed to cycle between story line 3 and 4 over a period of five years, with specific events in between that led to recalibration of his overall situation. For example, at one point, he seemed to be experiencing story line 4. Then he received a promotion and reevaluated his situation, deciding to stay. Later on however, another frustrating event occurred taking him back into story line 4 , at which point he decided to take a few months doing international medical work that he loved. His pattern over time points to three potentially important ideas that merit further study. First, individuals may travel among story lines over time, such as cycling between story lines 3 and 4, or perhaps as a progression whereby an opportunity becomes a problem, which escalates frustration, and then leads to a defining moment demanding escape. Second, there may be either contextual factors relating to the fact that Participant 14 was a trauma surgeon, a typically high-stress specialty, that may have played a role in bringing him repeatedly back into high-involvement story lines, or personality factors such as negative affectivity (Holtom, et al., 2012). Third, even if a strong pull toward leaving exists, the occurrence of positive events can proverbially reset the clock. Alternatively, there may be a latent negative temporal legacy that risks returning over time. The manner by which these processes evolve over time merits further study.

\section{Limitations}

Seven of the participants in this study were in the midst of their contemplation processes, allowing us to explore their thoughts in the moment. However, a potential limitation may be the reliance on retrospective interviews for 19 out of 26 participants who had either decided to leave or had made decisions to stay for the foreseeable future at the time of the interviews. Though significant contributions have been made based on such interviews (cf. Bartunek et al., 2008; Ibarra, 2003; Isabella, 1990; Schein, 1985), future longitudinal studies combining episodic surveys, interviews and participant journaling could 
provide a real-time understanding, at multiple time points, of how individuals interpret and re-interpret their situations, thereby reducing recall limitations and cognitive dissonance effects (Holtom et al., 2008).

We also knowingly embarked on this in-depth study using a sample from one population in a volatile work context. Although this sample provided rich insights, it may limit the generalizability of our findings. However, it is reasonable to expect that the contemplation framework and story lines will hold in other service professions, and that numerous social systems will be salient, regardless of the profession or context (Jansen \& Kristof-Brown, 2006). Ultimately, the extent to which findings apply in other settings and populations requires additional research in a variety of settings.

\section{Implications for Practice}

Study findings highlight four important implications for practitioners surrounding the process by which individuals contemplate workplace transitions, and subsequent retention or turnover.

Retention is an ongoing individualized process. Overall, findings point to the heterogeneous ways in which observable external events or circumstances were selected, construed and/or acted upon, even within this one context and population, depending on the overall construed situation at particular points in time. This, in turn, suggests the potential over-simplification by the popular press of the reasons for physician frustrations with and departures from this province. Changes in pay may be more or less salient for different individuals at different points in time. This may help in understanding why Fooks and colleagues (2002) reported so little impact of single interventions on health worker retention.

Findings suggest that effective one-time prescriptions across the board for minimizing workplace transitions likely do not exist. Instead, our findings suggest that retention should be an ongoing dialogic process where organizational actors are encouraged to engage in ongoing conversation, pulse-taking, and appropriately timed interventions. With roots in psychotherapy (Anderson \& Goolishian, 1992), storylistening and dialogic conversation practices have been gaining prominence in organizations (Cunliffe \& Eriksen, 2011; Tyler, 2011), and have proven to be highly effective within the field of organizational development (Bushe \& Marshak, 2009; Marshak \& Grant, 2008). We believe they could be equally effective to help prevent or delay workplace transition. This intervention requires an investment of time, 
mindful focus and effort on an ongoing basis. It also requires seeing retention as a strategic imperative to ensure that ongoing retention efforts are not buried beneath day-to-day urgencies.

Perhaps not surprisingly, we observed almost no evidence of story-listening or dialogic conversations occurring within our participants' work settings. We heard about exchanges of letters and the lack of responses to the voicing of concerns. However, by and large these were individually travelled thought processes, sometimes shared with families, friends and colleagues, but not with department heads. Whether this was due to a lack of interest by hospital senior management, a lack of understanding of how to optimally intervene, or lack of awareness that the thought processes were actually occurring is not known. However, many study participants expressed appreciation for the interview process. Participant 17 likened it to a "therapy session", as no one else had taken the time to listen to his concerns.

Differing story lines may require differing interventions. Whereas individuals may not be ready to share the fact that they are contemplating a transition, by engaging in conversations, practitioners may be able to begin to recognize the particular story line that an individual is experiencing and consider appropriate interventions. For example, for individuals in the solving problems story line, once the manager is aware of the problem, he or she can attempt to resolve it. However, for individuals who are attempting to reconcile incongruence, intervention options may be more limited, particularly if values incongruence exists (e.g., Schwepker, 1999). Even in this case, there may be an opportunity to intervene in the timing of a departure to help reduce short-term costs. Overall, whereas effective intervention is likely to be more challenging in story lines 3 and 4 when emotions and introspection are more prevalent, individuals across all story lines stand to benefit from open dialog and conversation.

Interventions should consider multiple levels of focal social systems. This study highlights the complexities surrounding the choice of appropriate level and method for intervening in this setting, whether by the Quebec government, professional associations, individual hospitals, departments within hospitals, or individual supervisors. In our observation of this complex context, each of these units operated in isolation from one another even though they combined to contribute to participants' overall assessment of their situations. Beyond engaging physicians in conversations within institutions, a more 
coordinated cross-level effort within the healthcare system may have been helpful for the health system overall. In addition, the buffering effect seen in this study, where positive perceptions in one focal social system seemed to mitigate the impact of frustrations with another, may be a useful lever for practitioners. For example, they may be able to "soften" the impact of events or circumstances at the government or industry level by attending to needs in the social systems over which they have more control within the organization. For Quebec healthcare in particular, the data suggests the possibility that context-self congruence at the hospital level may help attenuate negative developments at the health system level.

Escaping situations and disappearing from within as alternative forms of exit. The escaping situations story line raises awareness into an often unmentioned form of exit: psychological distancing as a form of coping. Even more noteworthy, at least four participants in this study effectively left their social systems without physically leaving their organizations at all. For example, one participant left the public system to work in the private system while remaining in the same physical office. Another left academic medicine while still continuing to work in his hospital. He simultaneously increased his time spent in the private versus public sector in what he referred to as "disappearing from within." Whether shifting between the public and private sector, community or academic medicine, or spending more or less time at work, this form of exit has serious implications while being much more difficult to identify and address than physical departures. As we begin an era of ubiquitous virtual and home offices and contingent workers, it may become increasingly important for practitioners to find appropriate methods for recognizing and circumventing this less visible form of exit.

In conclusion, the qualitative and inductive approach of this study allowed us to gain insight into the interpretive processes by which individuals contemplate workplace change. Findings provide a framework for understanding how individuals assess and revise their interpretation of specific aspects of themselves, their contexts, and the interaction of the two. The resulting framework fills an important temporal space between joining an organization and choosing to leave it. From a practice viewpoint, this study helps explain why preventing individual turnover is so difficult, and highlights the need for regular story-listening and dialogic conversations in order to affect the contemplation process in situ. 


\section{REFERENCES}

Abelson, R. P. 1963. Computer simulation of "hot" cognition. In S. S. Tomkins \& S. Messick (Eds.), Computer Simulation of Personality (pp. 277-302). New York: John Wiley and Sons, Inc.

Anderson, H., \& Goolishian, H. 1992. The client is the expert: A not-knowing approach to therapy. Therapy as social construction, 25-39.

Aquino, K., Griffeth, R. W., Allen, D. G., \& Hom, P. W. 1997. Integrating justice constructs into the turnover process: A test of the referent cognitions model. Academy of Management Journal, 40(5): 1208-1227.

Arthur, M. B., \& Rousseau, D. M. 1996. The boundaryless career as a new employment principle. In M. B. Arthur \& D. M. Rousseau (Eds.), The Boundaryless Career (pp. 3-20). New York: Oxford University Press.

Arthur, M. B. 1994. Effects of human resource systems on manufacturing performance and turnover. Academy of Management Journal, 37(3): 670-687.

Ashford, S.J., \& Taylor, S. 1990. Adaptation to work transitions: An integrative approach. Research in Personnel and Human Resource Management, 8: 1-39.

Association Médicale du Québec, 2006. Sondage Auprès des Médecins Omnipratiens et Spécialistes du Québec: Opinion des Médecins dur les Récentes Négotiations du Gouvernement et les Médecins Spécialistes, August.

Atkinson, R. 1998. The Life Story Interview, Sage University Paper Series on Qualitative Research Methods, 44. Thousand Oaks: Sage Publications.

Bamberger, P. A., \& Pratt, M. G. 2010. From the editors: Moving forward by looking back: Reclaiming unconventional research contexts and samples in organizational scholarship. Academy of Management Journal, 53(4): 665-671.

Bartunek, J. M., Huang, Z., \& Walsh, I. J. 2008. The development of a process model of collective turnover. Human Relations, 61(1): 5-38.

Bentein, K., Vandenberg, R., Vandenberghe, C., \& Stinglhamber, F. 2005. The role of change in the relationship between commitment and turnover: A latent growth modeling approach. Journal of Applied Psychology, 90: 468-482.

Berg, B.L. 2001. Designing qualitative research. Qualitative Research Methods for the Social Sciences (pp. 15-38). Boston, MA: Allyn \& Bacon.

Berger, P.L., \& Luckmann, T. 1966. The Social Construction of Reality: A Treatise in the Sociology of Knowledge. New York: Doubleday.

Billsberry, J., Ambrosini, V., Moss-Jones, J., \& Marsh, P. 2005. Some suggestions for mapping organizational members' sense of fit. Journal of Business and Psychology, 19(4): 555-570.

Bushe, G. R., \& Marshak, R. J. 2009. Revisioning organization development diagnostic and dialogic premises and patterns of practice. Journal of Applied Behavioral Science, 45(3), 348-368.

Cable, D. M., \& DeRue, D. S. 2002. The convergent and discriminant validity of subjective fit perceptions. Journal of Applied Psychology, 87(5): 875-884. 
Caplan, R. D. 1983. Person-environment fit: Past, present and future. In C. L. Cooper, Stress Research (pp. 35-78). John Wiley \& Sons, Ltd.

Cappelli, P. 2000. A market-driven approach of retaining talent. Harvard Business Review, 78(1): 103113.

Cappelli, P., \& Sherer, P. D. 1991. The missing role of context in OB: The need for a meso-level approach. Research in Organizational Behavior, 13: 55-110.

Charmaz, K. 1995. The body, identity and self: Adapting to impairment. The Sociological Quarterly, 26(4): 657-680.

Charmaz, K. 2006. Constructing Grounded Theory: A Practical Guide through Qualitative Analysis. Thousand Oaks, CA: Sage Publications.

Chase, S. E. 2005. Narrative inquiry: Multiple lenses, approaches, voices. In, N. K. Denzin, Y. S. Lincoln (Eds). The Sage Handbook of Qualitative Research, Third Edition, (pp. 651-680). Thousand Oaks, CA: Sage Publications.

Cohen, A. 1993. Organizational commitment and turnover: A meta-analysis. Academy of Management Journal, 36(5): 1140-1157.

Commission d'Etude sur les Services de Santé et les Services Sociaux, 2000. Les Solutions emergentes: Rapport et recommendations. Bibliotheque Nationale du Québec.

Cotton, J. L., \& Tuttle, J. M. 1986. Employee turnover: A meta-analysis and review with implications for research. Academy of Management Review, 11(1): 55-70.

Cowin, L. S., Johnson, M., Craven, R. G., \& Marsh, H. W. 2008. Causal modeling of self-concept, job satisfaction, and retention of nurses. International Journal of Nursing Studies, 45(10), 1449-1459.

Cunliffe, A. L., \& Eriksen, M. 2011. Relational leadership. Human Relations, 64(11), 1425-1449.

Czarniawska, B. 2004. Narratives in Social Science Research. London: Sage Publications.

Dawis, R.V., \& Lofquist, L.H. 1984. A psychological theory of work adjustment. Minneapolis: University of Minnesota Press.

Donnelly, D. P., \& Quinn, J. J. 2006. An extension of Lee and Mitchell's unfolding model of voluntary turnover. Journal of Organizational Behavior, 27: 59-77.

Dougherty, D. 1992. Interpretive barriers to successful product innovation in large firms. Organization Science, 3: 179-202.

Ebaugh, H. R. 1988. Becoming an Ex: The Process of Role Exit. Chicago, IL: University of Chicago Press.

Edwards, J. R. 1991. Person-job fit: A conceptual integration, literature review, and methodological critique. In C. L. Cooper \& I. T. Robertson (Eds.), International Review of Industrial and Organizational Psychology. Vol. 6, (pp. 283-357), John Wiley \& Sons, Ltd.

Edwards, J. R., Cable, D. M, Williamson, I. O., Lambert, L. S., \& Shipp, A. J. 2006. The phenomenology of fit: Linking the person and environment to the subjective experience of person-environment fit. Journal of Applied Psychology, 91: 802-827. 
Fooks, C., Duvalko, K., Baranek, P., Lamothe, L., \& Rondeau, K. 2002. Health human resource planning in Canada: Physician and nursing work force issues. Ottawa, ON: Commission on the Future of Health Care in Canada.

Gabriel, A. S., Diefendorff, J. M., Chandler, M. M., Moran, C. M., \& Greguras, G. J. 2014. The dynamic relationships of work affect and job satisfaction with perceptions of fit. Personnel Psychology, 67(2): 389-420.

Geertz, C. 1973. The Interpretation of Cultures. New York: Basic Books.

George, J. M., Jones, G. R. 1996. The experience of work and turnover intentions: Interactive effects of value attainment, job satisfaction and positive mood. Journal of Applied Psychology, 81(3): 318325 .

Gersick, C. J. G. 1991. Revolutionary change theories: A multilevel exploration of the punctuated equilibrium paradigm. Academy of Management Review, 16(1), 10-36.

Gibson, D. E. 2003. Developing the professional self-concept: Role model construals in early, middle, and late career stages. Organization Science, 14(5), 591-610.

Glaser, B. G. \& Strauss, A. L. 1967. The Discovery of Grounded Theory: Strategies for Qualitative Research, New York: Aldine de Gruyter.

Glesne, C. 1999. Finding your story: Data analysis. In Becoming Qualitative Researchers (pp. 130-154). New York: Longman.

Goldman, R. 2003. The life history interview method: Applications to intervention development, Health Education and Behavior, 30: 564-581.

Griffeth, R. W., Hom, P. W., \& Gaertner, S. 2000. A meta-analysis of antecedents and correlates of employee turnover: Update, moderator tests and research implications for the next millennium. Journal of Management, 26(3): 463-488.

Harlos, K. 2010. Anger-provoking events and intention to turnover in hospital administrators. Journal of Health Organization Management, 24(1):45-56.

Harman, W. S., Lee, T. W., Mitchell, T. R., Felps, W., \& Owens, B. P., 2007. The psychology of voluntary employee turnover. Current Directions in Psychological Science, 16: 51-54.

Harris, S. G., \& Mossholder, K. W. 1996. The affective implications of perceived congruence with culture dimensions during organizational transformation. Journal of Management, 22(4): 527547.

Hinkin, T. R. \& Tracey, J. B. 2000. The cost of turnover: Putting a price on the learning curve. Cornell Hotel and Restaurant Administration Quarterly, 41(3): 14-21.

Holtom, B. C., Burton, J. P., \& Crossley, C. D. 2012. How negative affectivity moderates the relationship between shocks, embeddedness and worker behaviors. Journal of Vocational Behavior, 80(2), 434-443.

Holtom, B. C., \& Inderrieden, E. J. 2006. Integrating the unfolding model and job embeddedness model to better understand voluntary turnover. Journal of Managerial Issues, 18(4), 435-452. 
Holtom, B., Mitchell, T., Lee, T., \& Eberly, M. 2008. Turnover and retention research: A glance at the past, a closer review of the present, and a venture into the future. Academy of Management Annals, 2, 231-274.

Holtom, B. C., Mitchell, T. R., Lee, T. W., \& Inderrieden, E. J. 2005. Shocks as causes of turnover: What they are and how organizations can manage them. Human Resource Management, 44(3): 337352.

Hom, P.W., Griffeth, R.W. 1995. Employee turnover. Cincinnati, OH: South-Western College Publishing.

Hood, J. C. 1983. Becoming a Two-job Family. Westport, CT: Praeger Publishers.

Ibarra, H. 2003. Working Identity: Unconventional Strategies for Reinventing your Career. Boston, MA: Harvard Business School Press.

Ibarra, H. 1999. Provisional selves. Administrative Science Quarterly, 44(4): 764-791.

Isabella, L. 1990. Evolving interpretations as a change unfolds: How managers construe key organizational events. Academy of Management Journal, 33: 7-41.

Jacobs, J. A., \& Gerson, K. 2004. The Time Divide: Work, Family, and Gender Inequality. Cambridge, MA: Harvard University Press.

Jansen, K. J. and Kristof-Brown, A. 2006. Toward a multidimensional theory of person-environment fit. Journal of Managerial Issues 18: 193-212.

Johns, G. 2006. The essential impact of context on organizational behavior. Academy of Management Review, 31(2): 386-408.

Johnson, R. E. \& Chang, C.-H. 2006. "I" is to continuance as "We" is to affective: The relevance of the self-concept for organizational commitment. Journal of Organizational Behavior, 27: 549-570.

Kammeyer-Mueller, J. D., \& Wanberg, C. R. 2003. Unwrapping the organizational entry process: Disentangling multiple antecedents and their pathways to adjustment. Journal of Applied Psychology, 88(5), 779-793.

Kammeyer-Mueller, J. D., Wanberg, C. R., Glomb, T. M., \& Ahlburg, D. 2005. The role of temporal shifts in turnover processes: It's about time. Journal of Applied Psychology, 90(4), 644-658.

Kaye, B., \& Jordan-Evans, S. 2008. Love 'em or lose 'em: Getting good people to stay. Berrett-Koehler.

Kelly, D. 2002. Contracts between physicians and governments need to change to reform our primary care system. Policy, 41.

Kling, K. C., Ryff, C. D., \& Essex, M. J. 1997. Adaptive changes in the self-concept during a life transition. Personality and Social Psychology Bulletin, 23: 981-990.

Kristof, A. L. 1996. Person-organization fit: An integrative review of its conceptualizations, measurement, and implications. Personnel Psychology, 49: 1-49.

Kristof-Brown, A. L., \& Jansen, K. J. 2007. Issues of person-organization fit. In C. Ostroff \& T. Judge (Eds.), Perspectives on Organizational Fit, SIOP Organizational Frontiers Series (pp. 123-153). Mahwah, NJ: Lawrence Erlbaum.

Langley, A. 1999. Strategies for theorizing from process data. Academy of Management Review, 24(4): 691-710. 
Langley, A. 2009. Studying processes in and around organizations. In D. Buchanan \& A. Bryman (Eds.) Handbook of Organizational Research Methods (pp. 409-429). London: Sage Publications.

Langley, A., Golden-Biddle, K., Reay, T., Denis, J. L., Hébert, Y., Lamothe, L., \& Gervais, J. 2012. Identity struggles in merging organizations: Renegotiating the sameness-difference dialectic. Journal of Applied Behavioral Science, 48(2): 135-167.

Larsen, R. J., \& Diener, E. 1987. Affect intensity as an individual difference characteristic: A review. Journal of Research in Personality, 21: 1-39.

Larsen, R. J., Diener, E., \& Emmons, R. A. 1986. Affect intensity and reactions to daily life events. Journal of Personality and Social Psychology, 51: 803-814.

Lau, D. C., \& Murnighan, J. K. 1998. Demographic diversity and faultlines: The compositional dynamics of organizational groups. Academy of Management Review, 23(2), 325-340.

Leduc, N., Bilodeau, H., Contandriopoulos, A-P, Sainte-Marie, G., Fournier, M-A \& Dandavino, A. 2001. L'Émigration des médecins québécois: Motifs de départ et de retour. Cahiers de Sociologie et de Démographie Médicales, 41(2): 221-238.

Lee, M. D., Kossek, E. E., Hall, D. T., \& Litrico, J-B. 2011. Entangled strands: A process perspective on the evolution of careers in the context of personal, family, work, and community life. Human Relations, 64: 1531-1553.

Lee, T. W. \& Mitchell, T .R. 1994. An alternative approach: The unfolding model of voluntary employee turnover. Academy of Management Review, 19: 51-89.

Lee, T. W., Mitchell, T. R., Holtom, B. C., McDaniel, L. S., \& Hill, J. W. 1999. The unfolding model of voluntary turnover: A replication and extension. Academy of Management Journal, 42: 450-462.

Lee, T. L. Mitchell, T. R., Wise, L., \& Fireman, S. 1996. An unfolding model of voluntary employee turnover. Academy of Management Journal, 39: 5-36.

Lewin, K. 1942. Field theory and learning. Yearbook of the National Society for the Study of Education, Part II, (215-239). Reprinted in 1997: Resolving Social Conflicts and Field Theory in Social Science. American Psychological Association.

Lincoln, Y.S., Guba, E.G. 1986. But is it rigorous? Trustworthiness and authenticity in naturalistic evaluation. In D. D. Williams (Ed.). New directions for program evaluation: A publication of the American Evaluation Association, 30: 73-84. San Francisco, CA: Jossey-Bass.

Louis, M. R. 1980. Surprise and sensemaking: What newcomers experience in entering unfamiliar organizational settings. Administrative Science Quarterly, 25, 226-251.

Luhmann 1995. Social Systems. Stanford, CA: Stanford University Press.

Maertz, C. P. \& Campion, M. A. 2004. Profiles in quitting: Integrating process and content in turnover theory. Academy of Management Journal, 47(4): 566-582.

Maertz, C. P., \& Griffeth, R. W. 2004. Eight motivational forces and voluntary turnover: A theoretical synthesis with implications for research. Journal of Management, 30: 667-683.

Markus, H., Wurf, E. 1987. The dynamic self-concept: A social psychological perspective. Annual. Review of Psychology, 38: 299-337. 
Marshak, R. J., \& Grant, D. 2008. Organizational discourse and new organization development practices. British Journal of Management, 19, S7-S19.

Maslach, C., Schaufeli, W. B., Leiter, M. P. 2001. Job burnout. Annual Review of Psychology, 52: 397422.

McAdams, D. P., Josselson, R. \& Leiblich, A. 2001. Turns in the road: Narrative studies of lives in transition. Washington, DC: American Psychological Association.

Miles, M. B., Huberman, A. M. 1994. Qualitative Data Analysis (2nd ed.). Thousand Oaks, CA: Sage.

Miller, E. M. 1986. Street Woman. Philadelphia, PA: Temple University Press.

Mintzberg, H., Raisinghani, D., \& Theoret, A. 1976. The structure of unstructured decision processes. Administrative Science Quarterly, 21(2): 246-275.

Mishler, E. G. 1986. Research Interviewing: Context and Narrative. Cambridge, Massachusetts: Harvard University Press.

Mitchell, T. R. Holtom, B. C., Lee, T. W., Sablynski, C. J., \& Erez, M. 2001. Why people stay: Using job embeddedness to predict voluntary turnover. Academy of Management Journal, 44: 1102-1121.

Mobley, W. H. 1982. Some unanswered questions in turnover and withdrawal research. Academy of Management Review, 7: 111-116.

Murray, H. A. 1938. Explorations in personality. New York: Oxford University Press.

Nicholson, N. 1984. A theory of work role transitions, Administrative Science Quarterly, 29(2): 172-191.

Nicholson, N., West, M. 1989. Transitions, work histories and careers. In M. Arthur, D. Hall, B. Lawrence (Eds.). Handbook of career theory: 181-201., Cambridge University Press.

Patton, M. Q. 2002. Qualitative research and evaluation methods. Thousand Oaks, CA: Sage.

Pelled, L. H., \& Xin, K. R. 1999. Down and out: An investigation of the relationship between mood and employee withdrawal behavior. Journal of Management, 25(6), 875-895.

Perls, F. 1973. The gestalt approach and eyewitness to therapy. Palo Alto, CA: Science and Behavior Books.

Peterson, M. F. 1998. Embedded organizational events. Organization Science, 9: 16-33.

Pettigrew, A.M. 1990. Longitudinal field research on change: Theory and practice. Organization Science, 1(3): 267-292.

Pineault, R., Contandriopoulos, A.P., \& Fournier, M.A. 1985. Physicians' acceptance of an alternative to fee-for-service payment: A possible source of change in Quebec medicine. International Journal of Health Services, 15(3): 428.

Pratt, M. G., Rockmann, K. W., Kaufmann, J. B. 2006. Constructing professional identity: The role of work and identity learning cycles in the customization of identity among medical residents, Academy of Management Journal, 49(2): 235-262.

Pratt, M.G. 2000. The good, the bad and the ambivalent: Managing identification among Amway distributors, Administrative Science Quarterly, 45: 456-493. 
Price, J. L. 1977. The Study of Turnover. Ames, Iowa: Iowa State University Press.

Price, S. 2009. Future directions for career choice research in nursing: A discussion paper. International Journal of Nursing Studies, 46(2): 268-276.

Reynolds, T. J., Gengler, C. E., Howard, D. J. 1995. A means-end analysis of brand persuasion through advertising. International Journal of Research in Marketing, 12: 257-266.

Roberts, B. W., \& Robins, R. W. 2004. Person-environment fit and its implications for personality development: A longitudinal study. Journal of Personality, 72(1), 89-110.

Rode, J. C., Judge, T. A., \& Sun, J. M. (2012). Incremental validity of core self-evaluations in the presence of other self-concept traits: An investigation of applied psychology criteria in the United States and China. Journal of Leadership \& Organizational Studies, 19(3), 326-340.

Ross, M. 1988. The relation of implicit theories to the construction of personal histories. Psychological Review, 96: 341-357.

Ross, M., \& Conway, M. 1986. Remembering one's own past: The construction of personal histories. In R. M. Sorrentino and E. T. Higgins (Eds.) Handbook of Motivation and Cognition (pp. 122-144). New York: Guilford Press.

Rusbult, C. E., Farrell, D. 1983. A longitudinal test of the investment model: The impact of job satisfaction, job commitment and turnover of variations in rewards, costs, alternatives and investments. Journal of Applied Psychology, 68: 429-38.

Schein, E. H. 1985. Career anchors: Discovering your real values. San Diego: University Associates.

Schein, E. H. 1996. Career anchors revisited: Implications for career development in the 21st century. Academy of Management Executive, 10(4), 80-88.

Schneider, B. 1985. Organizational behavior. Annual Review of Psychology, 36: 573-611.

Schwepker Jr, C. H. 1999. Research note: The relationship between ethical conflict, organizational commitment and turnover intentions in the salesforce. Journal of Personal Selling \& Sales Management, 19(1), 43-49.

Sheridan, J. E., Abelson, M. A. 1983. Cusp catastrophe model of employee turnover. Academy of Management Journal, 26(3): 418-436.

Shipp, A. J., \& Jansen, K. J. 2011. Reinterpreting time in fit theory: Crafting and recrafting narratives of fit in medias res. Academy of Management Review, 36(1): 76-101.

Solomon, Robert C. 1993. The philosophy of emotions. In M. Lewis \& J. Havil (eds.), Handbook of Emotions. Guilford Press.

Staw, B. M. 1981. The escalation of commitment to a course of action. Academy of Management Review, 6(4), 577-587.

Steel, R. P. 2002. Turnover theory at the empirical interface: Problems of fit and function. Academy of Management Review, 27(3): 346-360.

Steel, R. P., \& Lounsbury, J. W. 2009. Turnover process models: Review and synthesis of a conceptual literature. Human Resource Management Review, 19(4): 271-282. 
Strauss, A., Corbin, J. 1998. Basics of Qualitative Research: Techniques and Procedures for Developing Grounded Theory. Thousand Oaks, CA: Sage Publications.

Super, D., Starishevsky, R., Matlin N., \& Jordaan, J. P. 1963. Career development: Self-concept theory, College Entrance Examination Board.

Tsoukas, H. 1989. The validity of idiographic research explanations, Academy of Management Review, 14 (4): 551-561.

Tyler, J. A. 2011. Reclaiming rare listening as a means of organizational re-enchantment. Journal of Organizational Change Management, 24(1), 143-157.

Van den Hoonaard, W. C. 1997. Working with Sensitizing Concepts: Analytical Field Research. Thousand Oaks, CA: Sage Publications.

Van Maanen, J. 1998. Different strokes. In J. Van Maanen (Ed.) Qualitative Studies of Organizations. Newbury Park, CA: Sage Publications.

Waldman, J. D., Kelly, F., Aurora, S., \& Smith, H. L. 2004. The shocking cost of turnover in health care. Health Care Management Review, 29(1): 2-7.

Weick, K. E. 1995. Sensemaking in Organizations. Thousand Oaks, CA: Sage.

Weiss, H. M., \& Cropanzano, R. 1996. Affective events theory: A theoretical discussion of the structure, causes and consequences of affective experiences at work. Research in Organizational Behavior, $18,1-74$.

Witte, E. 1972. Field research on complex decision-making processes - The phase theorem. International Studies of Management and Organization, 2: 156-182.

Wrzesniewski, A., Dutton, J. E., \& Debebe, G. 2003. Interpersonal sensemaking and the meaning of work. In R. M. Kramer \& B. M. Staw (Eds.), Research in Organizational Behavior (Vol. 25, pp. 93-135). Amsterdam: Elsevier.

Youngblood, S. A., Mobley, W. H., Meglino, B. M., 1983. A longitudinal analysis of the turnover process. Journal of Applied Psychology, 68(3): 507-516.

Yu, K. Y. T. 2009. Affective influences in PE fit theory: Exploring the role of affect as both cause and outcome of PE fit. Journal of Applied Psychology, 94: 1210-1226. 


\section{Figure 1}

The Human Logic of Contemplated Workplace Transitions: Evolving Interplay among Triggering Stimuli, Focal Context, and Activated Self

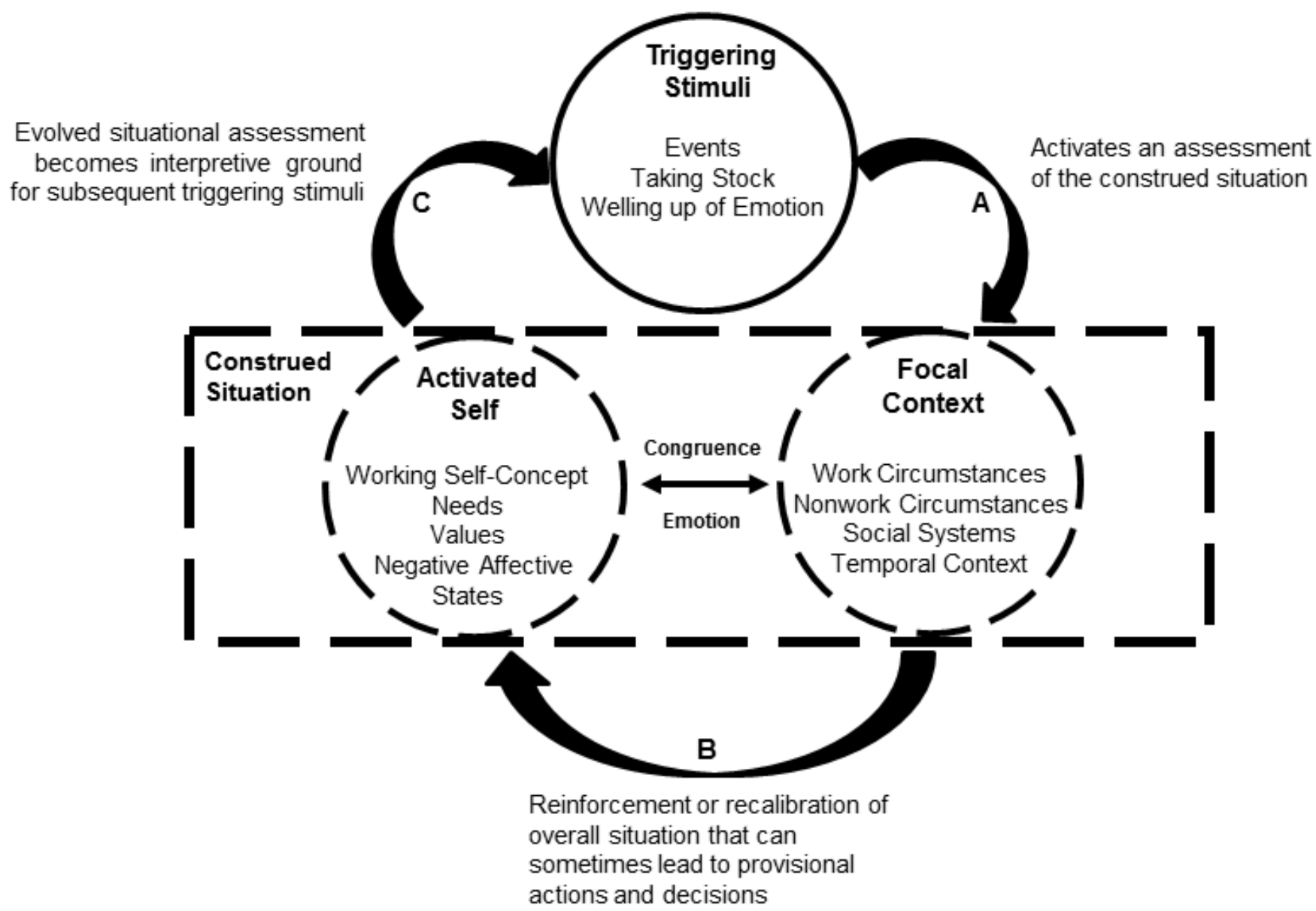




\section{Figure 2}

Four Dominant Story Lines Reflecting the Evolving Interpretation of Events, Self, and Context

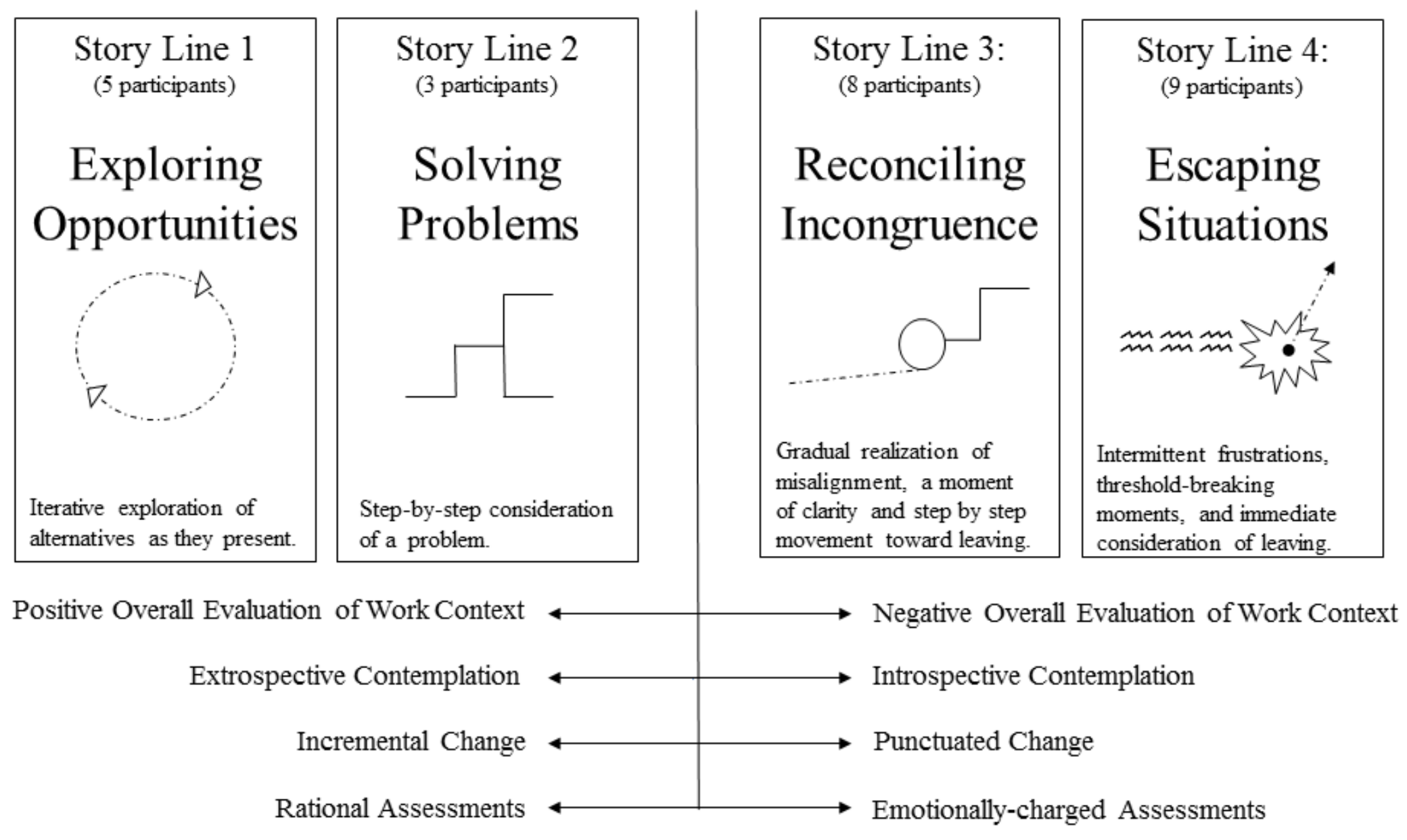

